\section{Ritual efficacy in the making}

\author{
Sébastien Galliot
}

Aix Marseille Université, CNRS, EHESS, CREDO UMR 7308, I333 I Marseille, France
Journal of Material Culture

20I5, Vol. 20(2) I0I-125 (C) The Author(s) 2015

(c) (i) (\$)

Reprints and permissions: sagepub.co.uk/journalsPermissions.nav DOI: $10.1177 / 1359183515578248$ mcu.sagepub.com

(\$)AGE

\begin{abstract}
As a contribution to the much debated problem of ritual efficacy, this article aims to present a technological approach to ritual theory. In most scholarly studies of ritual, analyses of the material setting are avoided in favour of a focus on symbolic expression, cultural representations, or embodied cognition. Here a close look at the interplay between substances, sounds, smells, elementary actions on matter and supernatural forces shows that there is a blending phenomenon between myth, rite and technique at the early stages of the preparatory phases as well as during the ritual action itself. The central part played by technical actions and interaction with matter in the ritual of Samoan tattooing is a case study for a technological approach to ritual efficacy.
\end{abstract}

\title{
Keywords
}

Body, ritual efficacy, Samoa, tattooing, technology

While the technique of tattooing using a perpendicularly hafted bone tipped instrument formerly known all over the Austronesian area has today been widely relearned according to the Samoan model and thanks to the technical expertise of the tufuga tā tatau (Samoan tattooing experts), no real research on the technology of tattooing has been undertaken since the publication of Samoan Material Culture 85 years ago (Buck, 1930). ${ }^{1}$ Milner $(1969,1973,1975)$ and Shankman $(1972,1975)$ did engage in a debate on the interpretation of the origin myth as an expression of a tripartite dualism: man/ tattooing/culture versus woman/parturition/nature. The first argued that the female counterpart of tattooing was procreation, the second that the existence of the female tattoo (malu) invalidated the former's structural analysis. Gell (1993), for his part, argued that Milner and Shankman were not asking the right questions because, in preChristian Samoa, there was a female rite of manual defloration which could, according to him, be considered the equivalent of male tattooing. In his work Wrapping in Images,

\footnotetext{
Corresponding author:

Sébastien Galliot, CREDO-Maison Asie-Pacifique, AMU, Campus St Charles, 3 place Victor Hugo, 13003 Marseille, France.

Email: sinapati@gmail.com
} 
he used the Samoan case to support his epidemiological thesis of a causal link between the intensity of the forms of tattoos (i.e. the quantity and position of these on the body) and the social system. Relying largely on Sahlins (1958) and Goldman's (1970) work, he adopts their division of Polynesia into three main types of political systems (conical, feudal and devolved) while neglecting the dynamic inherent to the societies he has taken as examples and leaving aside a good deal of contradictory ethnographic data. More recent work has enabled us to learn a little more about certain ceremonial aspects of Samoan tattooing and how the operation is carried out in the Auckland suburbs (Va'a, 2006) about the history of the changes resulting from the missionary presence or tattooing's transnational dimension (Galliot and Mallon, forthcoming; Mallon, 2005). However, the insular Samoan context of tattoo production was still missing from the anthropological literature. ${ }^{2}$

Using the fieldwork done in Samoa, Auckland and Wellington over a period of 24 months between 2001 and 2013 and following on from my doctoral thesis (Galliot, 2010a), my aim is to provide the ethnographic elements on which a technological approach to ritual efficacy can be developed. As has been recently recalled in this journal (Naji and Douni, 2009) and elsewhere (Lemonnier, 2004, 2010, 2012), the material and technical dimension of rites represents a relatively unexplored field of investigation. For so-called 'religious' anthropology is happy to leave the contingencies of matter aside in favour of more noble matters such as the sacred, the counter-intuitive, the symbolic or the performative. And when it is a question of action, this is never in the technological sense of elementary action on matter (Lemonnier, 1992: 4), but of ritualized action for various purposes. Though tattooing taken as a social institution is indeed a kind of technology of power (Foucault, 1977) intended to construct political subjects through operations on the body, tattoos as artefacts are the result of several other technical processes which, when studied, reveal the presence of agents that are 'hidden', so to speak, or manifest counter-intuitive properties (McCauley and Lawson, 2007).

In Samoa, the tattooing rite involves very few acts of language and consists of a series of operations on the patients' bodies, which are all 'efficacious traditional actions' (Mauss, 1936: 9): traditional because their transmission, although subject to variations, has a historical depth going back to the myth of the tools' importation; and efficacious because the action performed in the ritual context is intended to create a certain number of visual, physical and psychological effects. In this sense, the Maussian expression is not used merely as a slogan, as was suggested by Schlanger (1991: 114), but enables us to account for a specific articulation between techniques and efficacy in the ritual context. Moreover, the technological and procedural study of tattooing provides food for thought concerning a process in which an artefact is very concretely involved in the biological, psychological and social production of the subject. Knappett (2006: 239-241) looked at this question in a post-Cartesian framework considering mental activity as incorporated, situated and distributed. This led him, for example, along with others (he cites Le Breton, 2002; Gell, 1993; Kuwahara, 2005; Thomas et al., 2005), to define the tegumentary surface as a metaphysical border on which the mind acts through material actions such as tattooing or cosmetics. For all these authors, the action of tattooing does of course alter the bearer's skin and appearance but this is taken for granted even though it is responsible for a series of physical effects (pain, itching, swelling, thickening) which 
have to be analysed and included in the study of the co-construction of the subjects and objects if, as Knappett suggests, they intend to follow in Warnier's footsteps (Warnier, 1999). For the time being, the successful undertakings in this field can be counted on one hand. Warnier $(2007,2009)$ and Jeanjean (2006) are among the few researchers who have managed to mobilize an ethnography sufficiently rich to understand how representations of bodies and the techniques applied to these bodies are constituents of both the subjects and collectives.

The question of ritual efficacy applied to tattooing should not be confined to an analysis of 'what is done to the body' but should also take into account the conditions of the ritual's success, that is to say the material actions before and after the actual tattooing.

In the field of religious anthropology, the theme of ritual efficacy is both classic and recurrent. ${ }^{3}$ This 'problem' (e.g. Sax et al., 2010) is either taken in a causal sense - authors ask themselves in particular how a sorcery or healing practice achieves its purpose - or in the sense of social efficacy: they investigate how what is done or said in a ritual has a set of implicit aims that only anthropological analysis is capable of revealing (social function, actualization of a myth, condensation of antagonistic relations, staging of a political leader's power of social reproduction, etc.). In the case we are concerned with here, that is the creation of an image on the body through a series of actions, taking into account the rite's instrumental dimension and material conditions is not contradictory but fills a gap in the analysis of rites. In other words, the social efficacy of the tattooing ritual - in so far as it is based on a technical process involving agents, patients, as well as a set of different substances, tools and actions whose purpose is to create a work which, in order to be successful, must correspond to a certain number of evaluation criteria - is utterly dependent on the technical expertise of the master tattooist (tufuga tâ tatau) and his assistants: in a nutshell, on their technical efficacy. It is indeed the material basis of the rite that is the concern here as well as the material conditions, the series of actions and the results of these actions which are important to describe and analyse.

Consequently, whether we are dealing with Samoan tattoos, the Abelam's decorated yams (Coupaye, 2009, 2013), the Owa's sacred objects (Revolon, 2006, 2012) or the drums of the Ankave-Anga (Lemonnier, 2004, 2012), the ritual's materiality, that is to say the elementary actions on matter, the substances, tools, context of production, sounds and smells, as well as the representations linked to all these elements, is essential in the understanding of how certain artefacts acquire their power, their 'visual saliency' (in Gell's sense), their ritual efficacy.

In thus looking at technical processes and relations between matter and body, my approach is similar to that of an ethnographic tradition first developed in France by Mauss and Leroi-Gourhan which gave rise to 'cultural technology' (described in detail in Coupaye and Douny, 2009; Naji and Douny, 2009). This discipline made the description of operational sequences not only a device for observing a technical action but also an analytical tool that makes it possible to reveal the conditions of production (Cresswell, 1996) and, through these, the interweaving of social and technical elements from the very first operations of actions on matter (Balfet, 1975; Lemonnier, 1992). In this article, I propose a possible way of renewing the use of this descriptive tool by applying it to a series of actions in a ritual context. The difficulty lies in the fact that the purpose of the technical actions concerned is to modify living matter and that measuring its elasticity 
and resistance is not sufficient for grasping how the technical action results in a complex pictorial work. Here, we shall be dealing with the action of one body on another through the use of a tool. Therefore this technical action does not turn an inert and passive entity into a cultural object but human skin, the body's wrapping already modelled by society and part of the subject. Through the exteroceptive sensorial information it communicates, the skin contributes to the construction of the subject both on the cognitive level of body image (Schilder, 1935) and in their psychological development (Anzieu, 1989). And today, in order to understand both how, at the end of the sequence, the image of the body has been modified by the combined effect of actions, substances, and ritual participants and how the subject's sensorial experience is affected by certain material measures, ${ }^{4}$ technological analysis has the benefit of the praxeological and phenomenological approach that Warnier and the 'Matière à penser/Matter for Thought' group have been developing for several years.

Like Cresswell (2003), we could consider that a specific interest in sensorimotor behaviour is more to do with what he calls 'the far limit of the field of techniques' (p. 6), that is to say body techniques; but certain material actions performed prior to the operation manifest an indivisible mix of myth, rite and technique. In due course, I shall mention the importance of certain postural, spatial and instrumental constraints that are essential for the ritual's participants and that play an active part in this operation's efficacy. The difficulty and interest of making this practice an anthropological object lies therefore in the fact that it brings together several fields of research - those of technology, ritual and the body.

The cultural technology project of studying the human body and, in particular, clothing, decorations and body modifications is nothing new. Mauss, Haudricourt and LeroiGourhan formulated it long ago. However, though the sign value of adornment has indeed been the subject of innumerable sociological and ethnographic studies (Brain, 1979; Caplan, 2000; De Mello, 2000; Faris, 1972; Maertens, 1978; O’Hanlon, 1989; Taylor, 2003; Thévoz, 1984), its technological dimension, the question of the relation between matter and body, in short its 'praxis value' (Julien and Rosselin, 2009) has yet to be explored. It is evident that there are instances in which these questions may not be a priority or even pertinent but we shall see that in the case of Samoan tattooing these 'materialistic' concerns are legitimate.

My 'technological' approach to ritual efficacy is based on empirical data which, in the Samoan context, places a set of material and technical phenomena at the centre of the question of efficacy. Besides the relational configuration of the rite, its spatial configuration, the ritual prescriptions and proscriptions concerning behaviour, and the body techniques, the success of initiation by tattooing depends first and foremost on a set of technical acts aimed at constructing a ritual artefact and the efficacy of the rite itself rests on visual criteria. In other words, the ritual is a success if, and only if, it combines several elements: the presence of a master tattooist (tufuga tā tatau), the use of specific tools and the construction of a complex image. It is because this ritual is an activity requiring great technical expertise that we need to examine how technical processes, agents, matter, beliefs and supernatural forces are combined in it. Hence, in this article, I defend the point of view that this ritual's meaning does not lie in the semiological analysis of tattooing but in its physical effects and perceptive properties. 
In this sense, it seems to me that the distinction proposed by Alfred Gell (1988) between technical systems of production (aimed at satisfying material needs), reproduction (of human beings through training strategies) and enchantment (using material and immaterial devices intended as psychological weapons) is difficult to apply to our type of ritual activity. For not only does Samoan ritual tattooing combine these three dimensions (production of the work, reproduction of a social group by initiatory violence and enchantment of the person) at the time of the operation but the production of the tools and pigment - which could be considered purely technical processes subject to the causal properties of the matter to be transformed - is accomplished non verbally with the participation of supernatural agents, that is to say without the addition of magical formulae.

Thus my hypothesis is that the ritual's efficacy is guaranteed by a series of technical actions consisting of different ways of acting on a set of animal and vegetable materials and substances. Studying the matter, acts, technical actions, and sometimes the sounds and smells composing the ritual should enable us to understand that it is through material action that the mix of production, reproduction and 'enchantment' is obtained.

I have therefore been led to work outside the representational theories stating that, because rites are irrational and technically inefficacious, we should turn to the underlying representations, symbols, emotions and structures. This presupposition is latent in most theories on ritual. Frazer (1890) considered that from an instrumental point of view rituals were simply erroneous. It was in their symbolic expression and social functions that Durkheim (1954[1912]) saw the real efficacy of rites, thus introducing a distinction between instrumental and symbolic efficacy. Several major works have made it possible to go beyond this dichotomy based on a Western conception of science. By stressing the fact that practice has its own logic (Bourdieu, 1977), by underlining that the analogical functioning of magical and ritual acts (i.e. by a juxtaposition of utterances and instruments) requires taking into account their performative character (Tambiah, 1973), or by substituting the notion of ritualization for the concept of rite in order to study the context and the strategic nature of ritual action (Bell, 1992), the main works of the last 40 years have resulted in the ritual phenomenon being studied from almost every angle possible (Kreineth et al., 2006). Despite this massive reaction to representational theories, for the majority of researchers, the study of ritual action has retained a transitory status focused on social effect. In other words, while rites continue to be considered as systems of belief and actions organized into devices for social efficacy, their materiality is not seen as a subject worthy of interest, perhaps owing to the fastidious nature of technical analysis. Does Bourdieu (1982: 59) not stress that what is important in circumcision is not what is done to the boy but the 'social magic' through which it shapes a world in which male and female are distinguished? Milner (1969: 21) said much the same with regard to male tattooing in Samoa. Moreover, the belief that the materiality and technological dimension of the rite do not represent pertinent levels of analysis has led some anthropologists to consider rites as devoid of meaning (Staal, 1979) or to reject the very concept of ritual in favour of a Goffmanian analytical framework (small formal units of behaviour) or of approaches based on the analysis of specific cognitive processes (Goody, 1977). This idea has gained ground in so far as several top researchers (Boyer, 1994; McCauley and Lawson, 2002; Whitehouse, 2004) have developed particularly fruitful theories to define what a ritual is from the cognitive point of view and how it is passed on. 
The matter had almost been settled when Kapferer (1997: 178), criticizing the LéviStraussian opposition between the meaningfulness of myth and meaninglessness of ritual, emphasized the technological dimension of rituals. He suggested taking an interest in procedures rather than in approaches based on performance and Geertzian textual analysis (according to which rites are behavioural forms of communication in which it is important to explain the meaning of the religious symbols):

Ritual, or at least some events defined as rituals, can be grasped as technological apparatuses, not necessarily for the transmutation of nature into culture in Lévi-Strauss's sense, but as artifices or technologies designed to work within the elements and fabric of human constructive existence (physical, mental, material, relational, etc.) so as to (re)generate their personal, social, and cultural continuities and possibilities. (Kapferer, 2006: 672)

However, for him, the reality of rituals is virtual and the rite a technique for producing a 'phantasmagoric space', a virtual technology which provides the participants with a context enabling them to escape from the determinism of everyday life.

The phantasmagoric space of ritual virtuality may be conceived as a space (or a space opened by means of the virtual) whose dynamic not only interrupts prior determining processes but also is a space in which participants can reimagine (and redirect or reorient) themselves in the everyday circumstances of life. (pp. 673-674)

Thus, despite promising intentions, material actions are still not on the agenda. The implication of materiality and technical acts in ritual action is still not understood. My insistence on this aspect can be explained by the fact that the approaches summarized above largely ignore the interdependence between the operative character and the aesthetic dimension of a work which, in this case, is also the end result of a ritual.

With regard to art and aesthetics, Mauss rightly considered that all aesthetic objects are also technical because they are composed of a series of traditional acts intended to produce an effect. For him, the aesthetic effect of a work of art is different from the physical effect of a technique, both of these being different from the sui generis effect of religion, as some objets d'art may also have religious value. Unfortunately, for Mauss, tattooing seems to be just a plastic art whose designs need simply to be decoded and understood in their cultural context. This is probably why for him integumentary marks are no more than signs and symbols and seem only to require semiology (Mauss, 2007: 74-77). In fact, this is the approach still favoured in the anthropological literature on contemporary body markings (Falk, 1995; Krutak, 2007; Le Breton, 2002; McLane, 1996; Pitts, 2003; Sweetman, 1999). Thus, either the tattooed work continues, in coded language, to express membership or acceptance of a given system of values (ethnic group, punks, prisoners, bikers, to cite just the most obvious examples) or it is seen as an expression of individuality, a 'technique of the self', an 'art of existence' (in the Foucaldian sense, 1983), or an intimate mark of something its bearers cannot put into words.

The fact of creating a distinction between technology and aesthetics and, to be more precise, of separating body techniques not only from other instrumental techniques but also from the 'plastic arts' leads Mauss to attribute only adornment value to this form of 
art. He is not unaware and even asserts that in the study of tattooing, as a ritual action, particular attention must be paid to the actors and the different elements revealed during the initiation: a procedure largely neglected until today. Therefore, to study tattooing, the physical operations performed on the body and, in the final analysis, its aesthetic dimension, it is important to apprehend the ritual practice of tattooing as a technique which cuts across all the categories mentioned above. Indeed it was again Gell (1998) who had underlined the fact, without making a systematic study of it, that tattoos can also be active images whose formal characteristics and rules of construction need to be understood (pp. 105-111, 209-263). For the efficacy of tattooing taken as a technique of enchantment, a 'psychological weapon' whose visual saliency is thought to enhance the bearer's appearance and, in the Samoan context, to increase the dignity, mamalu, of his person - in short the 'magic' of tattooing - is not superior to the contingencies inherent to human action on matter. In proposing to study the interactions of materials, substances, acts and bodies in order to show how the efficacy, the agency, of tattooing is literally 'constructed' during the technical process, I am choosing a path similar to that taken by Warnier in The Pot-King (2007). It is a question of demonstrating that social efficacy (the construction of subjects and their integration into a category of people in the chieftainship's service) is based on technical acts. Tattooing is an image-making process. It therefore seems to me essential to take an interest in the operational mode and the materiality of the ritual in order to show that certain material aspects make it possible to understand better its discursive, mythical, interactional and sensorial dimensions.

\section{Of bones, blood and ink: The making and use of tattooing tools}

In the Samoan community (insular and diasporic), master tattooists (tufuga tā tatau) belong to a category of technico-ritual experts formerly common to the whole Polynesian region. In Samoa, tufuga can have various fields of specialization whether it be the building of boats or ceremonial houses, tattooing or circumcision. As the tattooing ritual is focused on the construction of a complex image, the tufuga tā tatau's knowledge is primarily technical. Becoming part of this category is not strictly hereditary and is achieved through a long apprenticeship which serves to perfect an innate aptitude and a gift generally understood as being of divine origin (o se mea'alofa o le Atua). Though today some have part of their tools and pigment made outside the archipelago, most still make their own tools and, more rarely, machine tools (drills, files, polishing stones). They are the guardians of the knowledge concerning the ritual procedures surrounding the operation (postures, order of the designs applied to the body, application of substances) and the most erudite among them sometimes know the corpus of myths relating to the origin of tattooing and assume a certain legitimacy in the exegesis of some decorative designs ${ }^{5}$ and the creation of new ones. However, in the Samoan context, these ritual experts' specialized knowledge has the particularity of seldom being verbalized and only objectified in technical actions. Thus a tufuga tā tatau displays or passes on his expertise exclusively through a hierarchized series of actions on matter, tools and persons. In fact, tufuga tā tatau distinguish themselves from Western tattooists by the fact that they use their judgement, their thinking (mafaufau), to apply a mental image through bodily actions (fa'atino) 


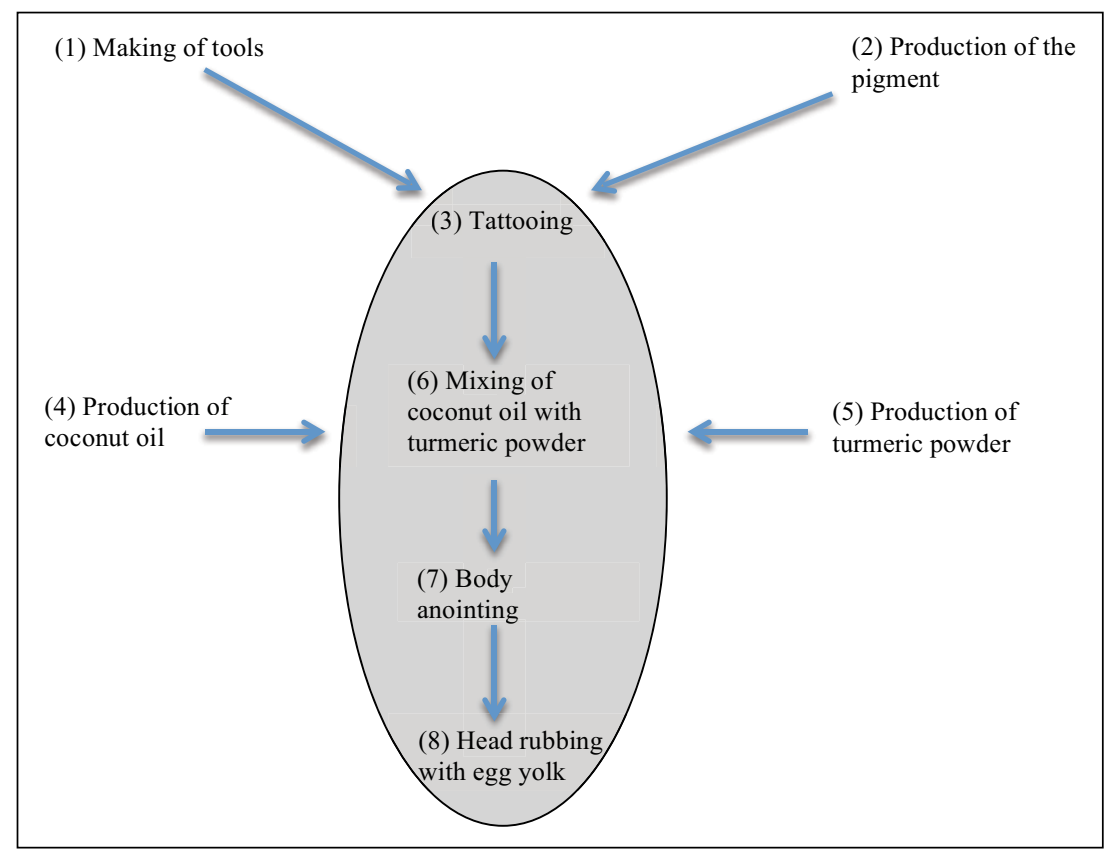

Figure I. General operational sequence for the production of tattooed subjects (the vertical ellipse marks the actions done during the ritual). (C) Sébastien Galliot.

while the others use a visual medium (a preliminary drawing on tracing paper or a photograph) which they redraw (tusi or tusitusi) with a tattoo machine.

Making a tattoo is reliant on several preliminary operations whose logical priority will be easily understood but which are the equivalent of 'strategic tasks' (Lemonnier, 1992: 21-24) for the efficacy of the ritual itself in so far as the transformation operations they bring into play make the revelatory aspect of the initiation possible. It is in this sense that the ritual moment of tattooing cannot be considered an isolated act but is part of a micro 'technical system' (Gille, 1979; Lemonnier, 1992) made up of a series of processes recapitulated below (Figure 1).

As my research problematic here concerns a technological approach to ritual efficacy, it is important to determine the most appropriate level of description (Lemonnier, 1992: 7). In order to show how certain material actions are decisive for the ritual's efficacy, it is essential to understand the role of the tools and pigment and, especially, to see that this production work which takes place prior to the rite already displays a specific mix of material and counter intuitive properties.

\section{The tools}

Every tufuga tā tatau possesses between three and five autā (hafted bone needles) of various widths (Figure 2): au mono (filling-in tool - in this context mono has the meaning of caulking) for ornamental designs, au sogi aso for straight lines, au sogi aso fa'aifo for 


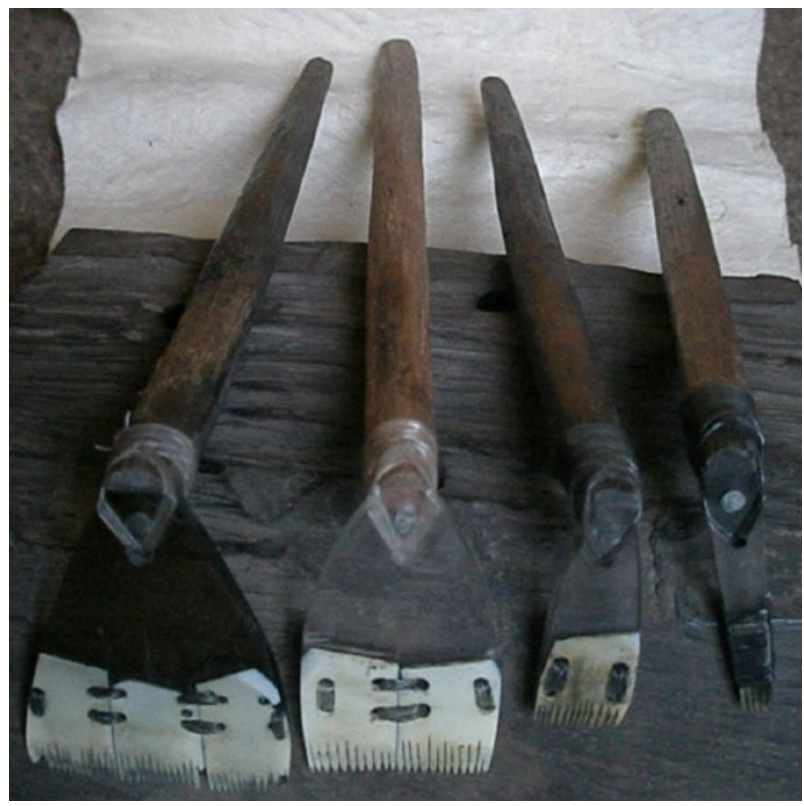

Figure 2. Set of au tā tatau (tattooing needles), tufuga tā tatau Su'a Loli Tikeli. (c) Photograph: Sébastien Galliot from his personal collection.

curved lines and au tapulu for solid black areas. Oral tradition recounts that these tools were introduced to Samoa during the extraordinary voyage of Taemā and Tilafaigā. These two Siamese twin deities are said to have given a basket of tools (atoau) and ceremonial privileges to some of their hosts in gratitude for the welcome they received. This founding act created two tattooing clans or 'äiga tufuga. In both these clans (Sā Su'a and Sā Tulouena), the set of tools is generally presented at the end of an apprenticeship and, when it has not been possible to train a successor in their use and to invest one with the right to use them, they are usually kept in the master tattooist's family. The possession of a set of tools thus materializes the genealogical tie linking its owner to the deities of tattooing.

Each kind of tool requires a certain type of percussion, a specific rhythmic tapping. The taps on the au mono with the least points correspond to a more intense rhythm of percussion (i.e. a greater number of taps in the same space of time) characterized by jerky tapping, while the taps on the widest (au tapulu) correspond to a slower percussion characterized by regular, stronger taps. In fact, due to the width of the au tapulu, a heavier striker (sausau) may be needed in using it. These tools are carefully cleaned and put away after use. The points which come into contact with the skin are sharpened from time to time and replaced only when they are too fine to be sharpened once more.

Making au tā tatau entails the crafting of three different parts: a wooden handle, a perspex (formerly turtle shell) plate and bone points. ${ }^{6}$ It is by paying particular attention to the stage in which the bone matter is transformed that we will be able to understand the place of material actions in the ritual as a whole. To be specific, we shall see how the making of 
Table I. Simplified operational sequence for the fashioning of the pig's tusk.

(I) extracting the tusk $\rightarrow$ (2) cutting into pieces $\rightarrow$ (3) polishing $\rightarrow$ (4) piercing $\rightarrow$

(2) Tipi

(3) Olo

(5) tying on the plate-ivory-handle $\rightarrow$ (6) sharpening/fining down the points

(6) Fa'amanifi

one single piece can have repercussions both on the beauty of the work and on what it reveals about the personality and the behaviour (amio) of the person receiving the tattoo.

The autā are assembled only after long crafting of the bones which will come into contact with the skin. Once the tattooist has the wooden handle and its plate which he has initially roughly carved, the rest depends entirely on the main piece of the tattooing tool, the sections of bone.

The serrated part of the tattooing tool is made from the lower tusks of wild pigs. ${ }^{7}$ This material, which according to some early missionaries' accounts has today replaced human bones, possesses properties rendering it good for tattooing. After polishing, this ivory can be cut into points fine enough to puncture the dermis without making too large a wound, while being sufficiently strong to resist the repeated taps of the sausau transmitted through the plate. The tusks must not have been cooked or heated to a high temperature for this makes the ivory fragile and impossible to turn into an au ta tatau. This poses a certain number of problems to Samoan tattooists who occasionally work abroad where sanitary standards require that all equipment be sterilized, an operation impossible to do on ivory without altering its properties of resistance to shock and dermis penetration. Table 1 summarizes the crafting of the ivory sections and Table 2 recapitulates the time needed for each tool-making operation.

Crafting the bone matter occupies between 60 per cent (for the au mono) and 80 per cent (for the au tapulu) of the total tool-making time. This relatively long production time can be explained by the properties of pig ivory which is a very resistant material and by the order in which the transformation operations are performed: polishing the enamel of the tusk's curved surface down to the dentine (the darkest part which indicates pulp calcification) before the other stages.

Some proverbs tend to assign a life of their own to the tools and in the origin myth of tattooing, it is the tools that play the role of mediators between the spirit world and that of men since they are the only material element introduced by the two tutelary spiritdeities. ${ }^{8}$ They are animate tools endowed with agency (they can break, make unusual wounds or show unusual resistance). Therefore, however skilled he may be, the tufuga's technical action consists of guiding them. Formerly, when not in use, they were carefully put away in a cylindrical wooden container (tunuma) and protected by a piece of tapa: they were then said to be sleeping together (momoe fa'atasi). The power attributed to these tools, and especially to the au mono (the narrowest one), can also operate in another context, a therapeutic one this time. Some tufuga tā tatau, but also some taulāsea, women healers, use them to remove birthmarks and to treat certain skin conditions in newborn babies. In these cases again, it is the tool to which the healing power is attributed.

We can see here how technical acts, elementary actions on matter, play an important role in the ritual's efficacy since it is the meticulous work of shaping the bone which will 
Table 2. Working time for each operation in the making of tattooing tools.

\begin{tabular}{|c|c|c|c|c|}
\hline & Au mono & $\begin{array}{l}\text { Au sogi'aso } \\
\text { fa'aifo }\end{array}$ & $\begin{array}{l}\text { Au sogi'aso } \\
\text { sasa'o }\end{array}$ & Au tapulu \\
\hline & $\begin{array}{l}\text { Filling in } \\
\text { tool }\end{array}$ & $\begin{array}{l}\text { Tools for } \\
\text { curved lines }\end{array}$ & $\begin{array}{l}\text { Tools for } \\
\text { straight lines }\end{array}$ & $\begin{array}{l}\text { Tools for solid } \\
\text { black areas }\end{array}$ \\
\hline \multirow{3}{*}{$\begin{array}{l}\text { Extraction of tusk + } \\
\text { cutting to shape }\end{array}$} & 30 & 30 & $30^{\prime}$ & $30^{\prime}$ \\
\hline & 5 & $5^{\prime}$ & 10 & $30^{\prime}$ \\
\hline & $=5^{\prime} 30^{\prime}$ & $=50^{\prime}$ & $=10^{\prime} 30^{\prime}$ & $=30^{\prime} 30^{\prime}$ \\
\hline Polishing of tusk & $30^{\prime}$ & $30^{\prime}$ & 60 & 90 \\
\hline Making of plate & 15 & 15 & 15 & 15 \\
\hline Making of handle & $20^{\prime}$ & $20^{\prime}$ & $20^{\prime}$ & $20^{\prime}$ \\
\hline $\begin{array}{l}\text { Tying up the plate to the } \\
\text { ivory section: }\end{array}$ & -5 & 8 holes: & I6 holes: & 24 holes: \\
\hline - boring & & 8' & $16^{\prime}$ & 24 \\
\hline \multirow[t]{2}{*}{ - fixing } & & 10 & $20^{\prime}$ & $30^{\prime}$ \\
\hline & & \pm 18 & \pm 36 & $\pm 54^{\prime}$ \\
\hline $\begin{array}{l}\text { Tying up the plate }+ \text { ivory } \\
\text { sections to the shaft: }\end{array}$ & 4 ' & 4 & 4 & 4 \\
\hline - boring & 5 & 5 & 5 & 5 \\
\hline - fixing & $\pm 9^{\prime}$ & \pm 9 & \pm 9 & $\pm 9^{\prime}$ \\
\hline Shaping the tusks & $40^{\prime}$ & 90 & 180 & 270 \\
\hline Total time per instrument & $\pm 124 ' 30$ & $\pm 187 ’ 30$ & $\pm 330 ’ 30$ & $\pm 488^{\prime} 30$ \\
\hline
\end{tabular}

allow the supernatural forces involved in the operation to be expressed. In other words, in order for this ritual object to be able to transform the initiates, it is not sufficient for it to be handled by an expert or invested with supernatural power using a magic formula or a performative expression. It must also be subjected to a technical process whose purpose is to use the causal properties of a material to their greatest advantage.

The sound produced on contact between an auta and the striker is also a sign of the tool's efficacy. A dull, non-vibrating sound (comparable to that of two drumsticks hitting each other) indicates a good design, well assembled parts. The au tā tatau is a composite object fulfilling mechanical requirements (skin penetration, resistance) but if it breaks during the operation, this is interpreted not as workmanship error but as a bad omen, the sign of unsuitable behaviour on the part of the patients or their family. The au ta tatau has the capacity to deliver a positive visual message but it can also make a scar on the patient's body. And this aspect is so present in local representations that, in 2007, a feature film entitled The Tattooist treated the theme of the tool's expression of supernatural forces in a paroxysmal way.

\section{The pigment}

Another element made prior to the ritual is the pigment, lama samoa, produced by burning nuts from the lama tree (Aleurites moluccana). It is different from other pigments 
Table 3. Simplified operational sequence for the production of lama samoa pigment.

(I) collecting the nuts $\rightarrow$ (2) sundrying $\rightarrow$ (3) roasting $\rightarrow$ (4) making the hearth $\rightarrow$

(I) tae lama

(2) fa'alā

(3) fa'avela

(5) opening the nuts $\rightarrow$ (6) placing the nuts in the hearth collecting the soot.

(5) ta'e lama

(7) burning $\rightarrow$ (8) collecting the soot.

(7) susunu lama

like lama kaleseni (made by burning benzene) or lama papalagi (Indian ink and industrial pigments). Lama samoa is seldom used today but has properties that deserve our attention. Whereas at the beginning of the century it was the responsibility of the patient's family, it is the tufuga who usually makes this pigment or, more correctly, manages its different stages of production. While the nuts can be collected by children, burning the seed they contain is a dangerous operation, likely to attract evil spirits, aitu, in particular because of the smell given off during its burning (manogi o aitu: smell of harmful spirits). For this reason, the transformation of the nuts into pigment was entrusted to two nofotāne; the word literally means '[woman] who lives at a man's estate [her husband or common-law husband]'. They did the burning in a shed specially reserved for the purpose and had to constantly 'watch over the flame' (täpua'i le afi) to make sure it did not go out (also see Buck, 1930; Krämer, 1994-1995[1902-1903]).

In the Samoan context, the notion of täpua' $i$ is crucial for understanding representations of actions (Ochs, 1988: 78, Tcherkézoff, 1995). In this case, the täpua'i involves voluntarily placing oneself under 'prohibitions', tapu, in order to perform a meditative prayer on which the success of the act will depend. The fire must never be left unattended for fear a spirit may touch the nuts and spoil the pigment or, more precisely, take away (avea) with it the lama's properties which give a perfect black colour (lanu uliuli; uli 'black', the repeated form marks emphasis). Table 3 is a simplified operational sequence for the production of lama samoa pigment. I have put the making of the hearth after the roasting of the nuts but it can take place at any moment before stage 6 .

The pigment's deterioration is called lama'avea. It can be attributed to bad management of the burning process, but it also indicates bad conduct on the part of the patient or one of his family members, or failure to respect one of the ritual prohibitions, $f a$ 'as $\bar{a}$, imposed by the tufuga. Lama'avea is also both a sign and a symptom of a disagreement between the patient's family and the tattooist's group. It is a kind of punishment by the spirits in order to make public bad behaviour or intentions. We should add too that the tattooist's wife, meana 'i tâua, may be responsible for the spoilt pigment in so far as she can actually be involved in its making. Here the potential capacity for remote action on the part of certain agents is only negative and must be contained by strict respect of the tufuga, his assistants and his rules. In each component of the technical microsystem leading to the tattoo-artefact, there are material operations which sanction the harmony between the different agents and their involvement in an aesthetic project. Here, the importance of personality and good relations in conditioning the quality of a performance recalls the work of Lortat-Jacob on vocal performances in Sardinia (Lortat-Jacob, 
1995), except that it is an artefact and not a sound manifestation of the the Virgin that is created. We will see how this kind of ordeal is expressed in the Samoan context.

\section{The operation}

The tattooing ritual marks the physiological development of the candidate for tattooing and his acquisition of cultural skills. I shall call him a patient not because of the medical nature of the operation but because patience (onosa $i$ ) is the main virtue during tattooing. The ritual's revelatory dimension is twofold. On the one hand, the pain of initiation reveals to the patient his own limits and the extent of his courage and, on the other, the tattooed image reveals to the group the patient's state of mind (good or bad) and the quality of the relations between the people involved in making the tattoo. Although in the past it was mandatory and sponsored by the chief of a district, today it can be the result of an individual decision or a collective (family) agreement to finance the operation. Some rituals, like birth celebrations (nunu fanau) no longer take place but, though it is optional today, tattooing remains a crucial moment in an individual's life in so much as it permanently, and in extreme pain, transforms the image of the body and its sensorial capacities. Moreover, it mobilizes a great deal of human and material resources which I have described in detail elsewhere (Galliot, 2010a). Before the ritual, a formal agreement is made between a member of the patient's family and the tufuga through a tauga (= gift of money, food or sometimes a fine mat, called fusitā on that occasion). To begin the ritual, the participants gather together and, either by holding a kava ceremony or with the aid of a churchman (a pastor or priest), create a sacralized space for the operation. This first sacralization stage - fa'apäia - marks the coming into effect of the ritual prohibitions.

Throughout the whole ritual (between ten days and three weeks), the body of the patient is subjected to a series of material measures and ritual prohibitions. It is precisely during this period that a coupling between efficacy, that is to say the tattooing's revelatory power, and the patient's compliant submission, which Gell (1993: 53-58) has very rightly described as 'passive heroism', is perceptible. At this stage of the operation, the body is the surface on which the future adult subjects are constructed. The patients are then referred to and addressed using a term corresponding to the position of their body during the operation and are called $o$ le ta'oto (the one who is lying down).

These are the prohibitions:

(1) Whereas the parts concerned by tattooing (abdomen, thighs, pubis and buttocks) are carefully shaved, they are not allowed to shave their beard (normally regularly removed).

(2) They must also take their meals separately.

(3) And not be sexually active.

(4) They are forbidden to walk about unaccompanied, especially at night for the liquids from their wounds (blood, ink, lymph) encourage attacks by aitu, spirits.

(5) In order to limit these discharges and help the wounds to heal, the tattooed members are massaged and soaped several times a day.

(6) Outside the tattooing sessions, they have to constantly drive flies away from their wounds using a little whip made with strips of plastic. 
Their lying-down position, the meaty smell from the wounds (one of the reasons some tattooists prefer menthol cigarettes which they smoke while working), the fact that flies are constantly kept away with fans or fly whisks, the necessity of saying silent prayers, täpua' $i$, are all elements reminiscent of corpses before their burial (Galliot, 2010a). They are entities with a problematic status where it is important that the body remains hidden but over which it is crucial to keep watch.

The patient's body, especially after the tattoo has been done using the traditional lama pigment, is considered hot, $m \bar{u}$. He is advised to sleep in a well-aired place, not on a mattress 'in European style' but on a sleeping mat or on a bed of nonu leaves (although the later is rarely observed nowadays). ${ }^{9}$ The leaves of this plant 'cool down' the tattoo wounds or rather absorb the heat they give off. The healing of the wound caused by the operation depends on correctly respecting all these rules, as well as the advice given to the patient to walk for a few minutes every day. These ritual and physical constraints form the measures intended to limit the harmfulness of the operation so that cases of death, serious infections or pigment deterioration are, in the final analysis, judged with regard to the patient's morality and the maintenance of good relations between his family and the tattooist's group rather than put down to medical causes or negligence by the tufuga tà tatau.

For their part, the participants have to obey a certain number of rules of conduct inside the space of the ritual action. Whatever the place may be (a hut at the back of the house, a room next to the main dwelling, a living-room or converted garage, in an urban, rural or diasporic context), the operation is performed on mats laid on the ground and all the participants must adopt a respectful (fa'aaloalo) attitude, materialized by wearing loincloths (lavalava) - shorts and trousers are banned - and by the absence of body decorations (flowers in the ear or necklaces) and perfume as well as by sitting cross-legged (fätai).

Apart from the tattooist and his assistants, the people sitting in the room where the operation takes place form the autapua' $i$ ('group which encourages the action by silent prayer'). As the days go by, a large number of people (fathers, uncles, aunts, cousins, friends) take turns at the patient's side to encourage the action and praise the future tattooed person's patience. The autāpua 'i perform various discreet acts: using a fan to drive away flies and air the wound, pressing down on his skull, hands or feet in order to 'distract his body'. The ethnologist taking photos and occasionally distributing cigarettes to the participants is also a member of the autapua'i. The tapua'iga (participation in the tapua'i) consists too in the repetition, at regular intervals, of expressions of encouragement in the order established below:

Mālō le sisila (silasila)! ('Congratulations on what we are observing')/Mālō le sausau! ('Congratulations on the percussions': the action of the expert who taps the top of the comb)/Mālō le a'ao solo! ('Congratulations on the busy hands')/Mālò le toso! (Congratulations to the assistants who are stretching the skin')/Mālo le onosa'i! ('Congratulations on the patience')/Màlō le ta'oto! ('Congratulations to the one lying down')

To which the assistants and the tufuga invariably reply:

'Mālō le tāpua 'i!' ('Congratulations on the tāpua 'i') 
The tattooist's (autufuga) work group represents the other pole of ritual action. It is part of the domain of doing, fai, as opposed to the domain of silent prayer, tapua' $i$. The tufuga and assistants are in direct contact with a specific matter which they must get to know. The skin and body of each patient are different in many regards. The skin's elasticity is obviously an important criterion for the tattooing operation, but its thickness, the way it reacts to injury, the presence or absence of naevi, the patient's hygiene, his possible obesity and his endurance are just as important. The fact that tufuga use two tools simultaneously prevents them from stretching the skin themselves. This technical constraint leads them to recruit several toso ('assistants responsible for stretching the skin') among their family and friends. In general, two toso stretch the skin and wipe away the surplus ink and blood, while a third, more mobile and less experienced, performs various tasks (stretching the skin, changing the dirty cloths, lighting cigarettes and collecting the ash, etc., see Figure 3).

The action of stretching the skin is central for two reasons. First, it makes the tattooing of straight lines possible. Then, it guarantees the insertion depth of the pigment and its permanence. I have performed this task several times, and the tufuga's frequent reprimands and the mediocre results on the patients' skin have made me aware of the importance of this dual function of the skin-stretching action. For several hours during the daily tattooing sessions, the assistants have to tightly stretch the skin with the flat of the hand in order to create as even a surface as possible. This presents a difficulty not immediately obvious to the observer for whom the assistants give the impression of performing routine gestures demanding little energy. In fact, this task involves sitting cross-legged for long periods (which can prove unbearable for foreign apprentices little accustomed to this position) and a movement of the upper body which is particularly painful for the forearm muscles and the trapezoid. The action of stretching the skin represents the first stage of apprenticeship to the profession of tattooist but nonetheless demands a certain skill for it entails adapting body techniques to the patient's body as well as to the master's idiosyncrasy. The assistants must therefore acquire precise knowledge of the structure and the elaboration stages of tattooing by the frequent repetition of the same actions and careful observation, in much the same way as that described by Martinelli (1996) for the Moose blacksmiths of Burkina Faso.

In addition, the toso's role does not end with the operation itself but also extends to the making of some of the tools as well as their preparation, cleaning and storage before and after the operation.

\section{Zoning, symmetry and contrast}

Just like canoe builders - tufuga fau va'a - and ceremonial house builders - tufuga fai fale (Buck, 1930: 22ff; Handy and Handy, 1924; Krämer, 1994-1995, II, $221 \mathrm{ff}$ ), makers of tattoos must respect an invariable construction plan. The latter concerns both the structure of the work to be created and the order in which the parts of the body are tattooed.

Male tattoos, $p e^{\prime} a$, and female tattoos, malu, are creations whose standardization is governed by two emic principles: the division of the skin's surface into different sections or zones (vāega) and the order in which the whole work is elaborated ('ava'ega). Tufuga 


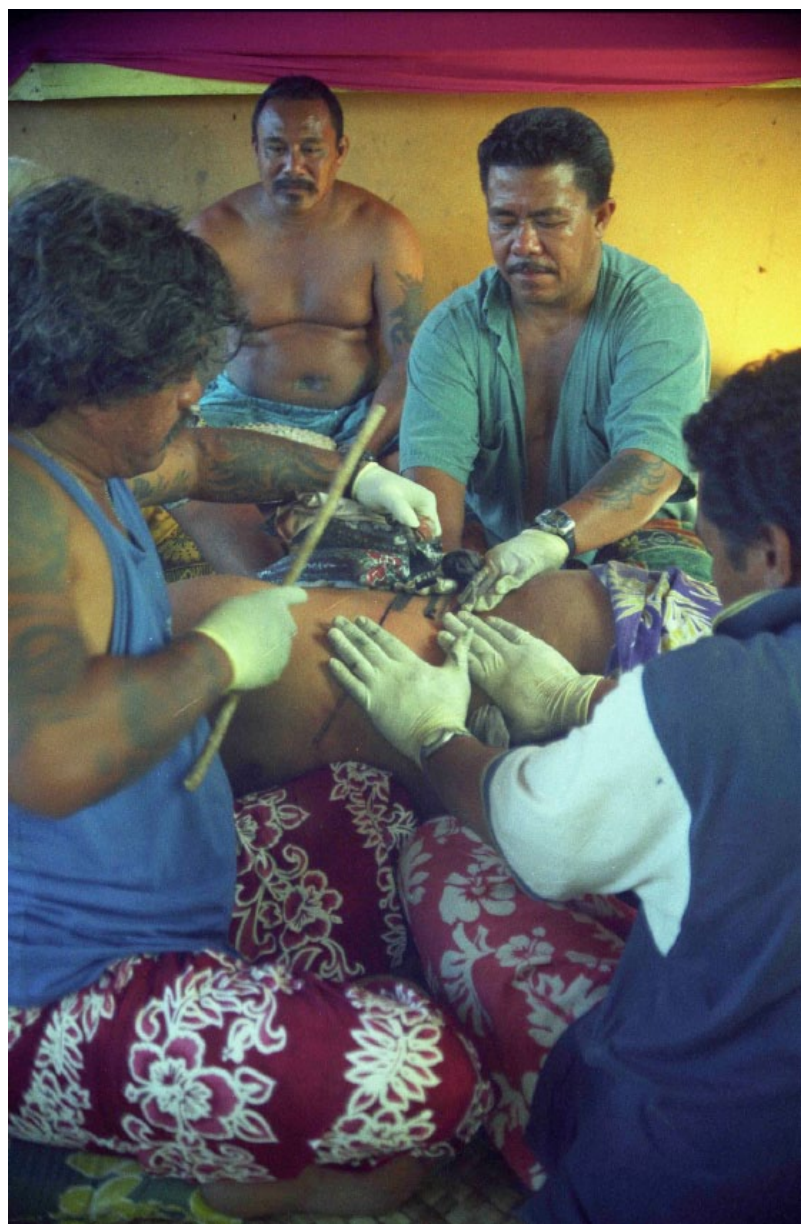

Figure 3. Tattooing operation in Apia, Samoa, June 200 I (Tufuga tā tatau: Sulu'ape Alaiva'a). () Photograph: Sébastien Galliot.

ta tatau often compare the creation of a tattoo to the building of a house, for in both cases the different operations must be carried out in a predefined order. As far as possible, the work must also respect a strict principle of symmetry. Symmetry centred on the body's vertical axis is a central evaluation criterion for a tattoo's quality.

Zoning (Greiner, 1923: 64) and the ordering of lines inside quadrangular sections have been identified as recurrent aesthetic principles of Samoan ornamentation (Kaeppler, 2005). However, in these publications, this central element remains a minor consideration compared to the pronounced attention given to the designs and their meaning. In addition, Kaeppler considers that the decoration of barkcloth, siapo, and tattoos is governed by the same principles. This can be called into question in so far as there is more 
freedom in the decoration of siapo regarding the delineation of the zones to be decorated. In tattoos, the designs, mamanu, vary very little and are limited by the shape of the tools, while those used for siapo are more diverse.

\section{What are these zones?}

The research I carried out with different tufuga led me to identify 18 zones, vāega, which I used as a base on which to reconstruct the prototype of a pe' $a$, that is to say a work valid and efficacious from the ritual point of view but free from all ornamentation (Figure 4). The elaboration of the whole follows a simple rule: the zones are tattooed from top to bottom and from back to front of the body. The different zones are thus done in the following order: for the top of the body from $b 1$ to $b 11$; for the thighs from b12 to b13 then from a3 to a5. The final stage of the tattoo concerns zones a6 to a8.

Technically speaking, the construction plan, the application order for the different sections, could be different but in fact it never varies. This invariability is the result of a 'technical choice' which is an integral part of the ritual knowledge. For quite some time, Lemonnier (1992) has stressed the heuristic value of 'the arbitrary' in understanding how this notion can play a role in technical transformations (p. 66). And in the case of tattooing, what is very interesting is that it is precisely this arbitrary element that has ensured the permanence of this form since at least the period of first contact in the early 18th century, while ornamentation has gone through remarkable diversification. In other words, the invariability of the construction plan of Samoan tattoos is the guarantee of their validity on a social level, of their aesthetic value and of the use the bearer will make of his tattoo. ${ }^{10}$ On another more theoretical level, this fact allows one to question the idea put forward by Gell (1993) that there may be a causal link between social organization and the intensity of tattooing. With regard to the Samoan case, it is legitimate to attempt to understand why this causal link has not led to the disappearance of tattooing or a radical transformation of its form in the context of the political and religious changes of the last 200 years.

Thus, in Samoa, tattoos are not merely drawings on the skin but genuine living artefacts used by bearers after their creation. For example, after the ritual they must be used in sexual intercourse, expressed in Samoan by the phrase fufulu le pe'a ('rubbed against' or 'rinsed with' a woman). During dances, tattooed men are encouraged to make them 'fly' (fa'alele le pe'a). Uncovering the upper body and exhibiting tattoos are also means of adopting a respectful form of behaviour in some public meetings.

\section{On the division of the body}

Far from corresponding to a strictly anatomical division of the body (leg, knee, stomach), the terms used to refer to the different zones are of various kinds. They can be anatomical like punialo (pubis), pute (navel), tua (bottom). They can be descriptive: for example, aso fa' aifo (curved lines) or aso läiti (small lines). Their shape and name can suggest creatures from the animal kingdom like the pe'a (flying fox) design, or the ulumanu (bird's head) zone. We are therefore dealing with a hybrid vocabulary that mixes names for designs specific to tattoos, whose meaning is often uncertain, with the names of parts 


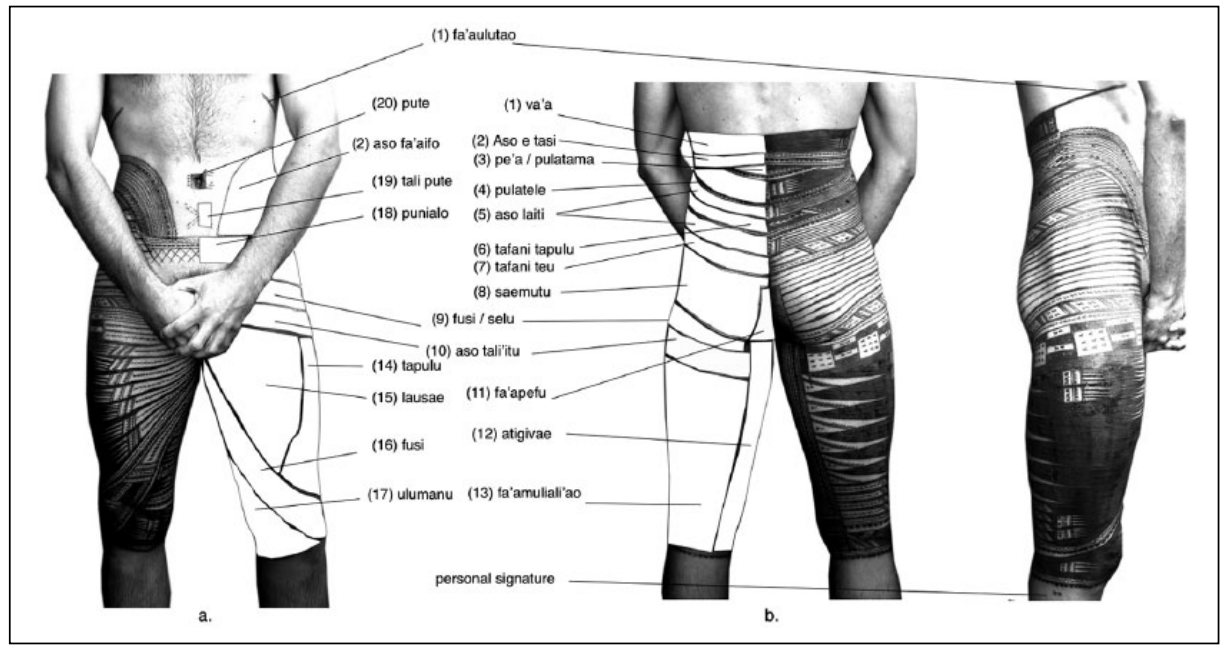

Figure 4. Male tattoo, pe'a: (a) front view; (b) back and side view. (C) Photograph: Sébastien Galliot.

of the body whether they are marked or not, as well as with words whose meaning is obvious and whose image refers more or less directly to the thing they represent. Although the name and sometimes the meaning of all the designs used are known, this esoteric knowledge is not very important during the ritual; it is not 'revealed' to the patient, nor is it ever explained.

Neither is the dividing of the body into zones intended to show physical aptitudes as can be the case in other societies (especially in South America) where some bodily treatments are intended to publicly signify the performance of an organ or a faculty (Seeger, 1981; Turner, 1992). In other words, there is no correspondence between the zone tattooed and the improvement or mediation of the faculties of the part of the body concerned. Thus, patients' bodies do not bear any particular personalized message but retain an attractive, visible mark of the ritual. This principle of segmenting the body into sections seems to be another technical criterion for the ritual's efficacy, just like the technical actions and sensorial environment already described. Instances of the ritual's failure are usually cases of unfinished or interrupted tattoos (pe'amutu), either due to the patient's weakness interpreted as a lack of courage or to unusual or persistent wounds appearing on their body. While a first set of index or omen mediated by the action of the tools on the skin can lead to inference about a 'problematic' patient, ritual failure can also be made visible through visual properties of the images such as an incomplete work. Ultimately, the way the skin reacts to the operation is an index of the quality of the relations between the various agents. For instance, the lightening of the pigment after the operation, unusual scars or a prolonged healing of the work denote a failure in building an acceptable social environment for the completion of the ritual. While no doctrinal knowledge is revealed during this initiation ritual, it however makes visible some features of the patient's interiority (his courage, his commitment to serve, his good spirit, among other things). 


\section{Ornamentation and criteria of beauty}

The ornamentation (teuga) is applied once each zone (vāega) has been outlined. On this level, the aesthetic conventions are more difficult to grasp in so far as each tufuga, using a limited decorative repertoire, creates a work he always claims is unique. I have discussed elsewhere how in these conditions family traditions and individual styles can emerge (Galliot, 2010a). Here I want more to underline two general principles which seem to govern ornamentation in male and female tattoos: repetition and contrast. First, each section is separated from the preceding one by a double line and a design marking the boundary (aso fa'atala). Added to this is an implicit filling-in rule which involves alternating dense and clear zones, thus creating a contrast which highlights each zone.

The different zones or sections are composed either of parallel lines or of small rectangular, triangular or trapezoidal units within which the governing principle is the repetition of the same design or sequence of designs.

In addition to the general alternation of clear and dense zones, the importance of contrast is obvious in the solid black areas, especially in the middle of the back and on the thighs where the ornamentation is done in the negative leaving clear spaces (fa'aila) on the dark surface. This visual effect is called $m \bar{a}$ ('to shine' in Samoan) which in this context means not the projection of light onto a reflective surface but a strong contrast between the pigment's blackening properties and the colour of the skin.

The beauty of a tattoo depends on its respect of the structure and the zoning principle I have just described. Then the intensity of the pigment, the sobriety of the ornamentation validate the beauty, mānaia, and the dignity, mamalu, of the work. On the other hand, too much ornamentation or the presence of unrecognizable designs leads to negative appraisals. Certain value judgements concerning the beauty of a tattoo can of course be a question of personal taste. Nonetheless, the technical particulars mentioned above, the construction of the image to be produced as well as the rules of ornamentation are used by the profession's elders as criteria for evaluating ritual efficacy. It is also these elders who can bring a young tattooist back into line if he takes too many liberties regarding ornamentation.

\section{Anointment and the aesthetics of ceremonial display}

Finally, let us examine a stage of the ritual which has not been mentioned. This is the closing ceremony, in particular the anointment of the tattoo (samaga). Taking place a few days after the end of the operation, this ceremony consists of a formal meeting between the patient's group and that of the tufuga. Apart from the exchange of thanks and the presentation of gifts to the tufuga, aspects we shall not be dealing with in detail here, this meeting begins with a moment of silent contemplation and a prayer said by a churchman or an elder from the patient's family. This sanctification phase ( $f a$ 'apāia $)$ is followed by two separate actions on the bodies of the tattooed patient (soga'imiti): the smearing of an egg on the top of the head (lulu'uga) by the tufuga and the anointing (sama) of the body with a mixture of coconut oil and turmeric by one of his assistants. While the first symbolically releases the co-initiates from the prohibitions ( $\mathrm{fa}^{\prime}$ 'anoa), replacing the green coconut water formerly used by an egg, the anointing is a more complex action. During 
the pre-Christian period in Polynesia and Micronesia, the combining of turmeric with coconut oil was part of the major seasonal rituals (Kirch, 1994; Lessa, 1966; Sopher, 1964), birth and puberty rites, and funerals (Firth, 1967; Galliot, 2010b; Parmentier, 1988; Turner, 1884). In Samoa, it is also employed as a medicinal preparation and its use in the closing tattoo ceremony is indeed linked to its antiseptic virtues and the relief it affords from the physical discomfort caused by tattooing. However, as this mixture was absent from the operation itself, its presence at the end of the ritual is intended to neutralize the potentially harmful effect of the pigment and to give the pe'a or malu a lustre and unusual colour. In the contemporary Samoan context, anointment can be interpreted as a ritual act ensuring a continuity between the ancient pre-Christian rites and ceremonies specific to the Polynesian region while at the same time being clearly recognized by Samoans (who are fervent Christians) as a action on the body omnipresent in the rituals of Christianity. Thus, whereas the inaugural prayer both Christianizes the rite and enables the opening of a sacred space, ${ }^{11}$ the oil, through its shininess, authorizes the presentation of the body in this space. The oil emphasizes the visual impact of the work, celebrates the person's successful initiation and guarantees they are correctly introduced to the ancestors embodied by the title-holders attending the event. Although indigenous aesthetics are beyond the scope of the present article, I would like to draw attention to the notion of brilliance. The enhancement of brilliance or shininess as partaking in the transPolynesian cosmology in which brightness, whiteness of things and people are favourable indexes of divinity has been stated by Tcherkézoff (2008: 122-123). In this particular ceremonial context, the effect created by this sacred oil, sama, on tattooed bodies provides it with a sheen which seems as appropriate to publicly display an ancestral image as Morphy (1989) showed when he dealt with the ritual value of brilliance among the Yolngu. In other words, and to follow Morphy's argument, here brilliance seems to operate cross-culturally and its role in the aesthetics of ceremonial display adds to the aesthetic qualities of the work of art (here the tattoo) quite independently of the specific meanings which can be encoded in the designs.

\section{Conclusion}

The aim of this article has been to propose a technological approach to ritual efficacy. In this undertaking, I have had to leave aside the social function, the symbolic and identity value of Samoan tattooing as a finished product, in order to concentrate on tattooing as a ritual artefact, some of whose stages of construction are decisive for the rite's efficacy. In other words, in order to understand how the participants perceive the efficacy of a ritual in which language plays a very limited role, it is essential to turn to the materiality of the rite, that is to say to investigate the interaction of objects, matter, bodies, sounds and smells, and supernatural forces in a structured environment.

On the one hand, the rite's efficacy depends on the making, by an expert, of an image which is standardized so that the viewer can recognize the prototype on which it is based. On the other hand, its success depends on the quality of the relations the patient and the people involved in the ritual have amongst themselves and with the tattooist's group. The tattooed image then becomes an indication of these relations in so far as it makes them visible on the bearer's skin. However, this level of appreciation of the tattoo (the visual 
properties of the ritual artefact) depends on certain earlier stages of the process of tool and pigment making, which are closely linked to the expert's technical knowledge and skill. This is why certain 'strategic tasks' (Lemonnier, 1992) like the shaping of the pieces of ivory or the burning of the lama nuts are crucial in localizing the actions in which counter-intuitive agents or supernatural forces intervene, making tattoos are not just body adornments but ritual artefacts endowed with a capacity for action. Finally, in the case of Samoan tattooing, to do without this technological approach which stresses material operations is tantamount to ignoring the role of the master tattooist's technical expertise in the rite's efficacy. In a way, here it is not what the deities do which is important but what the participants do to prevent the expression - always harmful - of supernatural powers.

\section{Acknowledgements}

I am grateful to Jean Paul Demoule and Ludovic Coupaye who gave me the opportunity to present this paper in the Culture materielle seminar at the Quai Branly Museum. I am especially indebted to Pierre Lemonnier for the close attention he gave to this work and for his inspiring presence, as well as to Ludovic Coupaye and Sandra Revolon for their helpful comments. Finally, I would like to acknowledge the translation work of Deborah Pope.

\section{Funding}

This work required several periods of fieldwork that were funded by the Ecole des Hautes Etudes en Sciences Sociales, the CREDO and the Observatoire NIVEA-CNRS. The writing stage of this paper has benefited from funding and material support from the Quai Branly Museum.

\section{Notes}

1. Robitaille (2007) nonetheless proposes a typology of Oceanian tattooing instruments based on the formal characteristics and their variations.

2. Only McGrevy (1973) has written an unpublished dissertation on Samoan tattooing but it contains no description of the ritual context.

3. See in particular Hubert and Mauss's text (1902-1903) and more recently two issues of the Journal of Ritual Studies (2010, Vols 1 and 2).

4. These are particularly pertinent themes for studying how the tattoo-object functions as a finished product, in other words for understanding how, through incorporation, tattoos as artefacts lastingly modify the subject's sensori-motricity.

5. It should be noted here that the correspondence between designs and their names is unstable and is therefore not a critical domain of knowledge for the efficacy and the transmission of the ritual. The names of the different designs remain dependent on the idiosyncrasy of each tattooist.

6. It is important to point out that, as I finish this article, most tufuga ta tatau are replacing this bone matter with steel needles for practical and aesthetic reasons. One of them, interviewed in September 2013, nonetheless acknowledged that in these conditions the ritual operation lost its revelatory character.

7. The selection criterion being that these undomesticated pigs are usually hunted at an advanced age for the length of their canines.

8. I use the terms spirits and deities indifferently because of the ontological uncertainty of these two Siamese twins. In oral tradition, they are sometimes seen as spirits (aitu) or figures 
from the hereafter (sauali'i) and they were also the object of local cults (Galliot and Mallon, forthcoming).

9. Various parts of the nопи (Morinda citrifolia) are used for their healing and antiseptic properties.

10. A crucial point for understanding the social functioning of this ornamentation is precisely the fact that it is not simply a decoration or an ethnic marker but an object which the bearers make use of (fa'aaogā le pe'a): they make it fly during dances (fa'alele le pe'a) and are meant to 'rinse' (fufulu le pe'a) it with a woman after the ritual, that is to use it in a sexual context oriented towards pregnancy and giving birth.

11. In Samoa, all formal meeting of chiefs (matai) involve the symbolic opening of such a space because, due to the title they hold, the presence of matai implies that of the title's original ancestor.

\section{References}

Anzieu D (1989) The Skin Ego. New Haven, CT: Yale university Press

Balfet H (1975) Technologie. In: Cresswell R (ed.) Éléments d'ethnologie 2: Six approches. Paris: Armand Colin.

Bell C (1992) Ritual Theory, Ritual Practice. New York: Oxford University Press.

Bourdieu P (1977) Outline of Theory of Practice. Cambridge: Cambridge University Press

Bourdieu P (1982) Les rites comme actes d'institution. Actes de la recherche en sciences sociales 43: 58-63.

Boyer P (1994) The Naturalness of Religious Ideas: A Cognitive Theory of Religion. Berkeley: University of California Press.

Buck P (Te Rangi Hiroa) (1930) Samoan material culture. Bishop Museum Bulletin 75.

Brain R (1979) The Decorated Body. London: Hutchinson.

Caplan J (ed) (2000) Written on the Body: The Tattoo in European and American History. Princeton, NJ: Princeton University Press.

Coupaye L (2009) Ways of enchanting: Chaînes opératoires and yam cultivation in Nyamikum village, Maprik, Papua New Guinea. Journal of Material Culture 14(4): 433-458.

Coupaye L (2013) Growing Artefacts, Displaying Relationship: Yams, Art and Technology amongst the Nyamikum Abelam of Papua New Guinea. New York: Berghahn.

Coupaye L and Douny (2009) Dans la trajectoire des choses: Comparaison des approches francophones et anglophones contemporaines en anthropologie des techniques. Techniques et culture 52-53, 'Technologies': 12-39.

Cresswell R (1996) Prométhée ou Pandore: Propos de technologie culturelle. Paris: Kimé.

Cresswell R (2003) Geste technique, fait social total: Le technique est-il dans le social ou face à lui? Techniques et culture 40.

De Mello M (2000) Bodies of Inscription: A Cultural History of the Modern Tattoo Community. Durham, NC: Duke University Press.

Durkheim E (1954[1912]) Elementary Forms of Religious Life. London: Allen \& Unwin.

Falk P (1995) Written in flesh. Body and Society 1: 95-105.

Faris J-C (1972) Nuba Personal Art. London: Duckworth.

Firth R (1967) Tikopia Ritual and Belief. Boston, MA: Beacon Press.

Foucault (1977) Discipline and Punish: The Birth of the Prison. New York: Pantheon Books.

Foucault M (1983) Usage des plaisirs et techniques de soi. Le Débat 5(27): 46-72.

Frazer J-G (1890) The Golden Bough. London: Macmillan.

Galliot S (2010a) Pe'a et Malu: Le tatouage à Samoa (1722-2010): Technique et culture dans une société de Polynésie occidentale en mutation. Unpublished PhD dissertation, EHESS, Paris. 
Galliot S (2010b) 'O le ta tatau': Couleur, tatouage et technique du corps à Samoa. In: Boetsch G et al. (eds) Décors des corps. Paris: CNRS, 265-273.

Galliot S and Mallon S (forthcoming) Tatau: A Cultural History. Wellington: Te Papa Press.

Gell A (1988) Technology and magic. Anthropology Today 4(2): 6-9.

Gell A (1993) Wrapping in Images. Oxford: Clarendon Press.

Gell A (1998) Art and Agency: An Anthropological Theory. Oxford: Clarendon Press.

Gille B (1979) La Notion de 'système technique': Essai d'épistémologie technique. Technique et culture I: 8-18.

Goldman I (1970) Ancient Polynesian Society. Chicago: Chicago University Press.

Goody J (1977) Against ritual: Loosely structured thoughts on a loosely defined topic. In: Moore S, Meyerhoff B (eds) Secular Rituals. Assen: Van Gorcum.

Greiner R (1923) Polynesian decorative designs. Bishop Museum Bulletin 7: 105.

Handy E-S-C and Handy W-C (1924) Samoan housebuilding, cooking and tattooing. Bishop Museum Bulletin 15.

Hubert H and Mauss M (1902-1903) Esquisse d'un théorie générale de la magie. Année sociologique 7: 1-146.

Jeanjean A (2006) Basses æuvres: Une ethnologie du travail dans les égouts. Paris: CTHS.

Julien M-P and Rosselin C (eds) (2009) Le sujet contre les objets ... tout contre: Ethnographies de cultures matérielles. Paris: CTHS.

Kaeppler A (2005) Animal designs on Samoan Siapo and other thoughts on West Polynesian barkcloth designs. Journal of the Polynesian Society 114(3): 197-225.

Kapferer B (1997) The Feast of the Sorcerer: Practices of Consciousness and Power. Chicago: University of Chicago Press.

Kapferer B (2006) Virtuality. In: Kreinath J et al. (eds) Theorizing Rituals: Issues, Topics, Approches, Concepts. Leiden: Brill, 671-684.

Kirch P (1994) The pre-Christian cycle of Futuna, Western Polynesia. Journal of the Polynesian Society 103(3): 255-298.

Knappett K (2006) Beyond skin: Layering and networking in art and archaeology. Cambridge Archaeological Journal 16(2): 239-251.

Krämer A (1994-1995[1902-1903]) The Samoan Islands, 2 vols. Honolulu: University of Hawai'i Press (translation of Die Samoan Inseln).

Kreinath J et al. (eds) (2006) Theorizing Rituals: Issues, Topics, Approaches, Concepts. Leiden: Brill.

Krutak L (2007) The tattooing arts of tribal women. London: Bennett \& Bloom/Desert Hearts.

Kuwahara M (2005) Tattoo: An Anthropology. New York: Berg.

Le Breton D (2002) Signes d'identité: Tatouages, piercings et autres marques corporelles. Paris: Métailié.

Lemonnier P (1992) Elements for an Anthropology of Technology. Ann Arbor: University of Michigan.

Lemonnier P (2004) Mythiques chaînes opératoires. Techniques et culture 43-44: 25-43.

Lemonnier P (2010) Vingt fois le « faire » est repensé: Ou quand l'action technique mobilise l'imaginaire. In: Cousin F, Pelras Ch (eds) Matières, manières et sociétés: Hommage à Hélène Balfet. Aix-en-Provence: Presses de l'Université de Provence.

Lemonnier P (2012) Technology. In: Thieberger N (ed.) The Oxford Handbook of Linguistic Fieldwork. Oxford: Oxford University Press, 298-316.

Lessa W-A (1966) Ulithi: A Micronesian Design for Living. NewYork: Holt, Rinehart and Winston. Lortat-Jacob B (1995) Sardinian Chronicles. Chicago: University of Chicago Press.

Maertens J-T (1978) Ritologiques I. Le dessein sur la peau: Essai d'anthropologie des inscription tégumentaires. Paris: Aubier Montaigne. 
Mallon S (2005) Samoan tatau as global practice. In: Thomas N et al. (eds) Tattoo: Bodies, Art, Exchange in the Pacific and the West. Durham, NC: Duke University Press.

Martinelli B (1996) Sous le regard de l'apprenti: Paliers de savoir et d'insertion chez les forgerons Moose du Yatenga (Burkina Faso). Techniques et cultures 28: 9-47.

Mauss M (1936) Les techniques du corps. Journal de psychologie 32, 'Sociologie et anthropologie': 363-386.

Mauss M (2007) Manuel of Ethnography. London: Berghahn.

McCauley R and Lawson T (2002) Bringing Ritual to Mind: Psychological Foundations of Cultural Forms. Cambridge: Cambridge University Press.

McCauley R and Lawson T (2007) Cognition, religious ritual, and archaeology. In: Kyriakidis E (ed.) The Archaeology of Ritual. Los Angeles: UCLA, 209-253.

McGrevy L (1973) O Le Ta Tatau: An examination of certain aspects of Samoan tattooing to the present. Unpublished $\mathrm{PhD}$, University of Hawaii.

McLane J (1996) The voice on the skin: Self-mutilation and Merleau-Ponty's theory of language. Hypatia 11: 107-118.

Milner G (1969) Siamese twins, birds and the double helix. Man 4(1): 5-24.

Milner G (1973) Siamese twins and Samoan tattoos. Man, New Series, 8(1):108.

Milner G (1975) Samoan tattoos and structural analysis. Man, New Series, 10(2): 307-308.

Morphy H (1989) From dull to brilliant: The aesthetics of spiritual power among the Yolngu. Man, New Series, 24(1): 21-40.

Naji M and Douny L (2009) Editorial. Journal of Material Culture 14(4): 411-432.

Ochs E (1988) Culture and Language Development: Language Acquisition and Language Socialization in a Samoan Village. New York: Cambridge University Press.

O'Hanlon M (1989) Reading the Skin: Adornment, Display and Society among the Wahgi. London: British Museum.

Parmentier R-J (1988) Transactional symbolism in Belauan mortuary rites: A diachronic study. Journal of the Polynesian Society 97(3): 281-312.

Pitts V (2003) In the Flesh: The Cultural Politics of Body Modification. New York: Palgrave Macmillan.

Revolon S (2006) 'Les esprits aiment ce qui est beau': Formes, sens et efficacité rituelle des sculptures owa (Est des îles Salomon). Annales de la Fondation Fyssen 21: 63-75.

Revolon S (2012) L'éclat des ombres: Irisation, contraste et présence des morts aux îles Salomon. Techniques et culture 58 (1): 252-263.

Robitaille B (2007) A preliminary typology of perpendicularly hafted bone tipped tattooing instruments: Toward a technological history of Oceanic tattooing. In: Gates St-Pierre C, Walker RB (eds) Bones as Tools: Current Methods and Interpretations in Worked Bone Studies. Oxford: Archaeopress.

Sahlins M (1958) Social Stratification in Polynesia. Seattle: University of Washington Press.

Sax W et al. (eds) (2010) The Problem of Ritual Efficacy. New York: Oxford University Press.

Schilder P (1935) The Image and Appearance of the Human Body. London: Kegan Paul, Trench, Trubner.

Schlanger N (1991) Le fait technique total: La raison pratique et les raisons de la pratique dans l'œuvre de Marcel Mauss. Terrain 1: 114-130.

Seeger A (1981) Nature and Society in Central Brazil: The Suyá Indians of Mato Grosso. Cambridge, MA: Harvard University Press.

Shankman P (1972) Siamese twins and Samoan tattoos. Man, New Series, 7(2): 314-315.

Shankman P (1975) Samoan tattoos and structural analysis. Man, New Series, 10(1): 126-128.

Sopher D-E (1964) Indigenous uses of turmeric (curcuma domestica) in Asia and Oceania. Anthropos 59: 93-127. 
Staal F (1979) The meaninglessness of ritual. Numen 26: 2-22.

Sweetman P (1999) Only skin deep? Tattooing, piercing and the transgressive body. In: Aaron M (ed.) The Body's Perilous Pleasures: Dangerous Desires and Contemporary Culture. Edinburgh: Edinburgh University Press, 165-187.

Tambiah S (1973) Form and meaning of magical acts: A point of view. In: Horton R, Finnegan R (eds) Modes of Thought. London: Faber \& Faber, 199-229.

Taylor A-C (2003) Les masques de la mémoire: Essai sur la fonction des peintures corporelles Jivaro. L'Homme 165: 223-248.

Tcherkézoff S (1995) L'autocar à Samoa ou la hiérarchie au quotidian. Gradhiva 18: 47-56.

Tcherkézoff S (2008) 'First Contacts' in Polynesia: The Samoan Case (1722-1848). Canberra: ANU Press.

Thévoz M (1984) The Painted Body. New York: Skira/Rizzoli.

Thomas N et al. (eds) (2005) Tattoo: Bodies, Art, Exchange in the Pacific and the West. Durham, NC: Duke University Press.

Turner G (1884) Samoa, a Hundred Years Ago and Long Before: Together with Notes on the Cults and Customs of Twenty-Three Other Islands. London: Macmillan

Turner T (1992) Social body and embodied subjects: Bodiliness, subjectivity, and sociality among the Kayapo. Cultural Anthropology 10(2): 143-170.

Va'a U-L-F (2006) Five days with a master craftsman. Fashion Theory 10(3): 297-314.

Warnier J-P (1999) Construire la culture matérielle: L'homme qui pensait avec ses doigts. Paris: PUF.

Warnier J-P (2007) The Pot-King: The Body and Technologies of Power. Leiden: Brill.

Warnier J-P (2009) Technology as efficacious action of objects ... and subjects. Journal of Material Culture 14(4): 459-470.

Whitehouse H (2004) Modes of Religiosity: A Cognitive Theory of Religous Transmission. Walnut Creek, CA: Altamira Press.

\section{Author biography}

Sébastien Galliot is research associate at the CREDO (Centre for Research and Documentation on Oceania, Marseille). He recently published Tatouages d'Océanie: Rites, techniques et images (Petits dossiers de la Société des Océanistes 2, Editions de la Société des Océanistes, 2014). He also co-edited the exhibition catalogue, Tattoo (Actes Sud/Musée du quai Branly). 
